\title{
Analisis Faktor-Faktor Yang Berpengaruh Terhadap Kinerja Pegawai Badan Pengelolaan Keuangan Daerah Propinsi Sulawesi Selatan
}

\author{
Hasmawati \\ STIE Indonesia Makassar \\ Email: fatwasullam@yahoo.com
}

\begin{abstract}
The aim of this research is to know and analysing of the influence of working motivation, working environment and working culture, towards the staffs' performance of financial management South celebest province and dominant factors analysis which influencing towards staffs performance. This research is caaried out at local financial management in South Celebes Province by utilizing 90 person as respondents. The data analysis used is a descriptive method by explaining the respondents chracteristics and variable description of research. Thus, the quatitave data analysis use multiple regression analysis throught the SPSS program for knowing the working motivation, working environment, working culture as the influence factors towards the staffs' performance whether simultanious or parcial. The result of this research shows that the simultanious whole independent varables observed positively influence the staffs's performance of local finacial management Board in the south celebes Province. It seems that the dominant factor influence the staffs' performabnce is the working environment. Based on the result of this research, it is recommendated to improve the staffs' performance of local financial management board of South celebes Province needs working motivation, working environment and working culture.
\end{abstract}

Key words : The influece of working motivation, working environment, working culture.

\section{Pendahuluan}

\section{Latar Belakang}

Peningkatan sumber daya manusia mempunyai kedudukan dan peran yang sangat penting dalam mengembangkan tugas pemerintah dan pembangunan, sangat perlu dibina dan diarahkan pada peningkatan kinerja secara optimal sesuai dengan promosi jabatan, perbaikan kesejahteraan menurut pangkat dengan dukungan dari lingkungan kerja yang baik, sehingga terdorong untuk melakukan berbagai kegiatan pelayanan secara professional dan tanggap terhadap aspirasi masyarakat dan perubahan lingkungan strategis dalam tatanan kehidupan nasional, regional dan global serta memberikan pelayanan kepada masyarakat.

Pegawai yang handal sangat dibutuhkan pada Provinsi Sulawesi Selatan khususnya pada Badan Pengelolan Keuangan daerah, mengingat ketatnya persaingan di segala bidang. Era globalisasi adalah masa yan penuh tantangan menjadi suatu peluang dibutuhkan 
Volume. 13, Nomor 2, Desember 2017

Halaman. 90-108
Analisis Faktor-Faktor Yang Berpengaruh

Terhadap Kinerja Pegawai Badan

Pengelolaan Keuangan Daerah Propinsi Sulawesi Selatan

kemampuan yang memadai dari setiap pelaku organisasi yang ditunjukkan dengan kinerja yang baik. Sumber daya manusia yang maju dalam kinerja pegawai negeri sipil pada Provinsi Sulawesi Selatan adalah pegawai yang turut berperan serta dalam penyelenggaraan pembangunan nasional dengan memberi sumbangsih berupa pemikiran baik dalam konsep perencanaan, program kerja serta pengendalian beberapa tugas pokok pelayanan kepada masyarakat menurut tingkat kapabilitas pegawai negeri sipil yang berprestasi dan professional menurut visi dan misi dan tujuan organisasi yang mengembangkan pelayanan kepada masyarakat.oleh karenanya dituntut adanya motivasi kerja yang tinggi dari pegawai negeri sipil sehingga dapat melaksanakan tugasnya baik secara intern maupun ekstern dengan menciptakan kondisi kerja yang kondusif dan dinamis dalam menyelesikan tugas.

Fenomena yang ada di Badan Pengelolaan Keuangan Daerah Provinsi Sulawesi Selatan menunjukkan bahwa motivasi kerja, lingkungan kerja dan budaya kerja merupakan factor-faktor yang berpengaruh tehadap kinerja pegawai pada Badan Pengelolaan Keuangan Daerah Provinsi Sulawesi Selatan. Untuk menetukan standar baku kinerja pegawai negeri sipil pada Badan Pengelolaan Keuangan Daerah Provinsi Sulawesi Selatan, maka perlu dilakukan suatu penelitian dan pengkajian yang lebih mendalam dan komperehensif dengan menentukan variable-variabel penting yang dianggap sangat berpengaruh terhadap kinerja pegawai.

Hal ini menunjukkan kesan bahwa kebanyakan pegawai sulit meningkatkan dan memperbaiki kinerjanya diakibatkan rendahnya pemberian kebutuhan motivasi kerja yang dilakukan oleh pimpinan instansi pemerintah di dalam memberikan kebijakan untuk mendorong, meransang dan mendukung pegawai untuk meningkatkan kinerjanya.

Secara alamiah, setiap orang pada setiap saat selalu diliputi kebutuhan, dan sebagian besar kebutuhan itu tidak cukup kuat untuk mendorong seseorang berbuat sesuatu pada suatu waktu tertentu. Kebutuhan akan menjadi suatu dorongan bila kebutuhan itu muncul hingga mencapai taraf intensitas yang cukup. Pemenuhan kebutuhan selalu diilhami oleh motif untuk memenuhinya. Atau dengan kata lain, motivasi dipakai untuk menunjukkan suatu keadaan dalam diri seseorang yang berasal dari akibat suatu kebutuhan.

Masalah motivasi bukanlah masalah yang mudah, baik dalam memahaminya maupun bagaimana menerapkannya. Tidak mudah karena berbagai alasan dan pertimbangan yang mesti dijadikan acuan. Akan tetapi dengan motivasi yang tepat para pegawai akan terdorong untuk berbuat semaksimal mungkin dalam melaksanakan tugasnya karena diyakininya bahwa 
Volume. 13, Nomor 2, Desember 2017

Halaman. 90-108
Analisis Faktor-Faktor Yang Berpengaruh

Terhadap Kinerja Pegawai Badan

Pengelolaan Keuangan Daerah Propinsi Sulawesi Selatan

dengan keberhasilan organisasi mencapai tujuan untuk dan sasarannya, maka kepentingankepentingan pribadi para anggota organisasi tersebut akan terpelihara pula (Siagian 2000).

Badan Pengelolaan Keuangan Daerah sebagai organisasi pemerintah sebagaimana organisasi pada umumnya, dalam pencapaian tujuan tidak luput dari berbagai macam fenomena motivasi kerja pegawainya yang pada gilirannya pula akan berdampak pada kinerja baik individu maupun organsiasi. Olehnya itu perlu ada suatu kajian yang mendalam terhadap masalah tersebut sehingga bisa ditentukan formasi yang tepat dalam organisasi.

Melihat fenomena nyata tersebut maka motivasi sangat dibutuhkan oleh seorang pegawai dalam meningkatkan kinerjanya. Motivasi penting karena dengan motivasi diharapkan setiap individu atau karyawan mau bekerja keras dan antusias untuk mencapai produktivitas kerja yang tinggi. Dengan demikian motivasi mempersoalkan bagaimana caranya mendorong gairah kerja bawahan agar mau bekerja keras sesuai dengan kemampuan dan keterampilan yang dimiliki untuk mewujudkan tujuan organisasi/instansi.

Motivasi merupakan daya pendorong yang mengakibatkan seseorang anggota organisasi mau dan rela untuk mengerahkan segenap kamampuan dalam bentuk keahlian atau keterampilan, tenaga dan waktunya untuk menyelenggarakan berbagai kegiatan yang menjadi tanggung jawabnya dan menunaikan kewajibannya, dalam rangka pencapaian tujuan organisasi. Jadi motivasi merupakan kesediaan untuk mengerahkan usaha tingkat tinggi untuk mencapai tujuan organisasi. Hanya saja perlu dipahami bahwa kesediaan untuk mengerahkan usaha pencapaian tujuan organisasi tersebut sangat tergantung pada kemampuan seseorang untuk memuaskan berbagai kebutuhannya. Artinya suatu kebutuhan yang belum terpuaskan dapat menciptakan ketegangan yang pada gilirannya menimbulkan dorongan tertentu dalam diri seseorang. Untuk menghilangkan ketegangan tersebut seorang karyawan harus melakukan usaha tertentu (Siagian, 2004)

Selain Motivasi kerja hal yang tidak kalah pentingnya adalah bagaimana menciptakan suasana kerja yang aman,nyaman dan kondusif dalam menunjang aktivitas kerja dari semua unsur organisasi. Sehingga semua pegawai dapat bekerja dengan baik dan menghasilkan pekerjaan yang optimal. Disamping itu juga diperlukan suatu jaminan berupa pemberian motivasi berupa insentif dan penghargaan untuk memacu kinerja pegawai agar senantiasa bekerja dengan penuh tanggung jawab yang baik.

Pegawai negeri sipil pada Badan Pengelolaam Keuangan Daerah Provinsi Sulawesi Selatan dalam menjalanan tugasnya sebagai abdi Negara dan pelayan masyarakat perlu 
Volume. 13, Nomor 2, Desember 2017

Halaman. 90-108
Anatisis Faktor-Faktor Yang Berpengaruh

Terhadap Kinerja Pegawai Badan

Pengelolaan Keuangan Daerah Propinsi Sulawesi Selatan

mendapat penghargaan atas jerih payah yang merekasumbangkan pada masyarakat dan Negara. Oleh Karena itu, perlu mengkaji dan menganalisis variabel motivasi kerja, lingkungan kerja dan budaya kerja pengaruhnya terhadap kinerja pegawai pada Badan Pengeloaan Keuangan Daerah Provinsi Sulawesi Selatan.

Faktor-faktor tersebut menjadi hal yang menarik untuk dicermati dan menjadi fenomena yang melatar belakangi dilakukannya penelitian ini untuk dapat mengimplementasikan standar baku dari kinerja pegawai dan mendorong penulis untuk mengangkat judul, "Analisis Faktor-faktor yang berpengaruh terhadap Kinerja Pegawai pada Badan Pengelolaan Keuangan Daerah Provinsi Sulawesi Selatan”

\section{Tinjauan Pustaka}

\section{Sumber Daya Manusia}

Sumber daya manusia adalah sebuah konsep yang relatif masih baru dalam dunia manajemen dan organisasi, dan menjadi populer sejak awal dekade tahun tujuh puluhan, tatkala riset ilmu prilaku menunjukkan bahwa pengelola manusia atau tenaga kerja dianggap sebagai sumber daya dari pada hanya sebagai faktor produksi yang akan memberikan manfaat nyata bagi organisasi atau perusahaan.

Sumber daya manusia dianggap sangat penting peranannya dalam mencapai tujuan organisasi, maka berbagai pengalaman dan hasil penelitian dalam bidang sumber daya manusia dikumpulkan secara sistematis yang dikenal dengan istilah manajemen.

Pengertian sumber daya manusia yang dikemukakan oleh Nawawi (2000:40) sebagai berikut :

1. Sumber daya manusia adalah manusia yang bekerja di dalam organisasi (disebut juga personil, tenaga kerja, pekerja atau karyawan).

2. Sumber daya manusia adalah potensi manusia sebagai penggerak organisasi dalam mewujudkan eksistensinya.

3. Sumber daya manusia adalah potensi yang merupakan asset dan berfungsi sebagai modal di dalam organisasi bisnis yang dapat diwujudkan menjadi potensi nyata secara fisik dan non fisik dalam mewujudkan eksistensi organisasi.

Menurut Veithzal (2003:1) Manajemen sumber daya manusia merupakan salah satu bidang dari manjemen umum yang meliputi segi-segiperencanaan, pengorganisasian, pelaksanaan dan pengendalian yang merupakan proses dalam fungsi/bidang produksi, 
Volume. 13, Nomor 2, Desember 2017

Halaman. 90-108
Anatisis Faktor-Faktor Yang Berpengaruh

Terhadap Kinerja Pegawai Badan

Pengelolaan Keuangan Daerah Propinsi Sulawesi Selatan

pemasaran, keuangan maupun kepegawaian. Selanjutnya Mathis dan Jackson (2002:4) memberi pengertian manajemen sumber daya manusia, sebagai sesuatu yang berhubungan dengan sistem rancangan formal dalam suatu organisasi untuk menentukan efektivitas dan efisiensi, dilihat dari bakat seseorang untuk mewujudkan sasaran suatu organisasi.

Sumber daya manusia merupakan sentral dalam upaya untuk mewujudkan eksistensinya berupa tercapainya tujuan organisasi. Kemampuan sumber daya manusia yang dimiliki tersebut harus mampu menyesuaikan diri dengan tuntutan kemajuan ilmu pengetahuan dan teknologi, kebijakan pemerintah dan perubahan lingkungan.

Seiring dengan perkembangan zaman, saat ini sangat dibutuhkan kualitas sumber daya manusia yang handal dan unggul. Sumber daya manusia yang berkualitas mempunyai peranan yang penting dalam pengembangan dan peningkatan aktivitas kerja, secara khusus berkitan dengan kinerja yang efektif dan efisien, maka ada suatu batasan bahwa kualitas sumber daya manusia adalah suatu bentuk aktualisasi kerja dari pegawai dalam memberikan pelayanan yang prima kepada masyarakat, sehingga masyarakat dapat memberikan penilaian terhadap kemampuan pegawai tersebut.

Hai ini berarti, suatu kualitas sumber daya manusia adalah memberikan suatu pelayanan prima kepada masyarakat dan masyarakat merasa mendapat suatu pelayanan prima tersebut, dengan sendirinya terjadi umpan balik yaitu pegawai dinilai memiliki kinerja yang efektif dan efisien atas pelayanan yang diberikan sesuai dengan tugas pokok dan fungsinya.

Subarkah (2000:201) bahwa kualitas sumberdaya manusia sangat ditentukan oleh individu dan institusi sumberdaya manusia. Kualitas sumberdaya manusia dapat tercermin dari manajemen sumberdaya manusia yang diterapkan berdasarkan tingkat kompetensi kerja yang berdasarkan pada tingkat pendidikan yang dimiliki, keterampilan, pengalaman kerja dan penguasaan teknologi.

\section{Motivasi Kerja}

Untuk mengerti makna tentang motivasi kerja perlu memahami lebih dahulu pengertian motif dan motivasi. Motif adalah suatu dorongan yang ada dalam diri seseorang untuk berbuat sesuatu, baik berupa gerakan maupun ucapan. Sedangkan motivasi adalah tindak lanjut dari motif yaitu perbuatan gerakan, baik berupa ucapan maupun tindakan serta perilaku dalam cara-cara tertentu yang dilakukan seseorang (Siagian, 2004). 
Volume. 13, Nomor 2, Desember 2017

Halaman. 90-108
Analisis Faktor-Faktor Yang Berpengaruh

Terhadap Kinerja Pegawai Badan

Pengelolaan Keuangan Daerah Propinsi Sulawesi Selatan

Menurut Mangkunegara (2005) motivasi terbentuk dari sikap (attitute) pegawai dalam menghadapi situasi kerja pada suatu unit kerja tertentu. Motivasi merupakan kondisi atau energi yang menggerakkan diri pegawai yang terarah atau tertuju untuk mencapai tujuan organisasi.

Menurut Winardi (2001:4) apabila mempelajari berbagai macam pandangan dan pendapat tentang motivasi, maka dapat ditarik kesimpulan bahwa motivasi berkaitan dengan perilaku dan kinerja, serta motivasi mencakup pengarahan kearah tujuan. Sedangkan menurut Handoko (1998) motivasi adalah keadaan dalam pribadi seseorang yang mendorong keinginan individu untuk melakukan kegiatan-kegiatan tertentu guna mencapai tujuan.

Koonts dan Jones (Siagian, 2004) mengemukakan bahwa motivasi mengacu pada dorongan dan usaha untuk memenuhi dan memuaskan kebutuhan atau untuk mencapai suatu tujuan. Menurut Robinson, (1999:50) mengatakan bahwa motivasi adalah kesediaan untuk melaksanakan upaya tinggi untuk mencapai tujuan-tujuan keorganisasian, yang dikondisikan oleh kemampuan upaya untuk memenuhi kebutuhan individual tertentu sesuai dengan hasil kerja.

Uraian tersebut dapat disimpulkan bahwa motivasi adalah suatu dorongan yang dapat menggerakkan seseorang untuk melakukan kegiatan dan menimbulkan semangat dan gairah kerja yang mengarah pada tercapainya suatu tujuan tertentu.

\section{Lingkungan Kerja}

Lingkungan dan sarana teknologi merupakan salah satu faktor yang sangat mempengaruhi proses pelaksanaan kegiatan dalam rangka mencapai produktivitas kerja pegawai.

Menurut Sutrisno (2000:5), kantor merupakan tempat dilaksanakanya aktivitas kerja organisasi dan berfungsi sebagai tempat pemberian pelayanan kepada masyarakat. Karena orentasi pelayanan adalah kepuasan, maka untuk memenuhinya diperlukan lingkungan yang kondusif untuk tugas-tugas pelayanan olehnya itu analisis berdasarkan diagnosa lingkungan kerja dewasa ini merupakan hal yang paling mendasar bagi institusi publik yang berorentasi pelayanan terhadap masyarakat.

Kualitas sarana produksi, dalam penilaian ini analog dengan fasilitas operasional yang dimiliki oleh seorang operator komputer, berpengaruh terhadap peningkatan produktivitas. Apabila fasilitas operasional yang digunakan tidak baik kadang-kadang dapat menimbulkan pemborosan biaya operasional yang digunakan, Sedarmayanti (2001:76) 
Volume. 13, Nomor 2, Desember 2017

Halaman. 90-108
Anatisis Faktor-Faktor Yang Berpengaruh

Terhadap Kinerja Pegawai Badan

Pengelolaan Keuangan Daerah Propinsi Sulawesi Selatan

Pada dasarnya aspek teknologi mencakup empat komponen utama yang terintegrasi, yakni : (1) teknologi yang terkandung pada manusia yang terdiri atas pengetahuan, keterampilan, sikap, perilaku, dan budaya, (2) teknologi yang terkandung dalam barang berupa mesin-mesin, peralatan produk (barang dan atau jasa). Teknologi ini membantu manusia dalam melakukan tugas, (3) teknologi yang terkandung dalam kelembagaan organisasi dan manajemen. Teknologi ini membantu manusia untuk dapat bekerja secara lebih efektif dan efisien, dan (4) teknologi yang terkandung dalam dokumen-dokumen berupa informasi yang dihasilkan manusia untuk membantu dalam melakukan pekerjannya. Teknologi ini dapat tersimpan dalam dokumen paten, rumus-rumus, gambar, buku-buku, majalah, disket, microfilm dan lainnya Gasperez, (1998:17-18)

Dengan demikian berdasarkan uraian di atas, bahwa lingkungan dan sarana teknologi merupakan hal yang paling penting mendasar bagi institusi publik untuk membantu dalam meningkatkan produktivitas kerja pegawai dalam rangka pelayanan masyarakat.

\section{Budaya Kerja}

Budaya kerja adalah prinsip-prinsip yang diyakini baik dan benar dalam mencapai tujuan perusahaan atau organisasi. Budaya kerja menjadi landasan setiap kebijakan dan aturan, serta mengarahkan perilaku individu di dalam perusahaan/organisasi. Prinsip-prinsip dikenal sebagai nilai-nilai perusahaan/organisasi dankeyakinan. Kebijakan dan aturan antara lain norma-norma,standar-sandar dan ukuran-ukuran. Hasil budaya kerja dapat diamati dan dirasakan melalui perilaku setiap individu alam oganisasi. Termasuk antara lain iklimkeerja (hubungan,komunikasi, gaya kepemimpinan) dan tindakan-tindakan simbolik (pemberian penghargaan, dan upacara peringatan). Membangun budaya kerja merupakan suatu investasi dan pondasi keberadaan untuk jangka panjang.

Budaya kerja merupakan suatu falsafah yang didasari oleh pandangan hidup sebagai nilai-nilai yang menjadi sifat, kebiasaan dan kekuatan pendorong, membudaya dalam kehidupa suatu kelompok masyarakat atau organisasi,kemudian tercermin dari sikap menjadi perilaku, kepercayaan, cita-cita pendapat dan tindakan yang terwwujud sebagai "kerja" atau "bekerja".melaksanakan budaya kerja mempunyai arti yang sangat dalam, Karena akan merubah sikap dan perilaku sumber daya manusia untuk mencapai produktivitas kerja yang lebih tinggi dalam menghargai tantangan masa depan (Triguna, 1995:3). 
Volume. 13, Nomor 2, Desember 2017

Halaman. 90-108
Analisis Faktor-Faktor Yang Berpengaruh

Terhadap Kinerja Pegawai Badan

Pengelolaan Keuangan Daerah Propinsi Sulawesi Selatan

Wolseley, Camplbell dan Triguna (dalam Teguh Djiwanto 2006:9) menyatakan bahwa orang yang terlatih dalam kelompok budaya kerja akan mempunyai sikap:

1. Menyukai kebebasan,pertukaran pendapat, dan terbuka bagi gagasan-gagasan baru dan fakta baru dalam usahanya untuk mencari kebenaran.

2. Memecahkan permasalahan secara mandiri dengan bantuan keahliannya berdasarkan pengetahuan, pemikiran yang kreatif, dan tidak menyukai penyimpangan dan pertentangan.

3. Menyesuaikan diri antara kehidupan pribadinya dengan kebiasaan sosialnya.

4. Mempersiapkan dirinya dengan pengetahuan umum dan keahlian khusus dalam mengelolah tugas dan kewajiban dalam bidangnya.

5. Memahami dan menghargai lingkungan

6. Berpartisipasi dengan loyal kepada kehidupan rumah tangga,masyarakatdan organisasi serta penuh rasa tangung jawab.

Menurut Nawawi (2003) budaya kerja adalah kebiasaan yang dilakukan berulangulang oleh pegawai dalam suatu perusahaan, pelanggaran terhadap kebiasaan ini memang tidak ada sangsi yang tegas, namun dari perilaku organisasi secara moral telah menyepakati bahwa kebiasaan tersebut merupakan kebiasaan yang harus ditaati dalam rangka pelaksanaan pekerjaan untuk mencapai tujuan. Budaya kerja akaan bermanfaat dalam organisasi tatkala masing-masing pegawai saling mebutuhkan sumbang saran dari teman sekejanya, naun budaya kerja ini akan berkibat buruk apabila pegawai dalam instansi tersebut mengeluarkan egonya masing-masing karena dia berpedapat dia dapat bekerja sendiri tanpa bantuan orang lain.

Dari defenisi tersebut,rasanya jelas bahwa seseorang mempunyai budi pekerti, taat pada agama, dan memiliki nilai-nilai luhur akan mempunyai kinerja yang baik, dalam arti mau bekerja keras,jujur,anti KKN, serta selalu berupaya memperbaiki kualitas hasil pekerjaannya demi kemajuan perusahaan.

\section{Kinerja Pegawai}

Kinerja merupakan istilah yang berasal dari kata job performance atau actual performancei (prestasi kerja atau prestasi sesungguhnya yang dicapai seseorang). Definisi kinerja karyawan yang dikemukakan Kusriyanto (Mangkunegara, 2000) adalah perbandingan hasil yang dicapai (produktivitas) dengan peran serta tenaga kerja per satuan waktu (lazimnya perjam). Kinerja sebagai suatu proses yang berkaitan dengan aktivitas sumber daya manusia dalam melakukan pekerjaan yang ditugaskan. Mengingat kinerja adalah aktivitas yang 
Volume. 13, Nomor 2, Desember 2017

Halaman. 90-108
Analisis Faktor-Faktor Yang Berpengaruh

Terhadap Kinerja Pegawai Badan

Pengelolaan Keuangan Daerah Propinsi Sulawesi Selatan

berkaitan dengan unsur-unsur yang terlibat dalam suatu proses, maka pencapaian hasil (output) yang diinginkan adalah standar suatu kerja dalam organisasi.

Menurut Gordon (1993) bahwa "performance is a function of employe's ability acceptance of goal. Level goals and the interaction of goal with their ability”. Dengan demikian, kinerja ditentukan oleh faktor-faktor kemampuan, motivasi dan kesempatan. Kesempatan kerja adalah tingkat-tingkat kinerja yang tinggi yang sebagian merupakan fungsi dari tidak adanya rintangan-rintangan yang mengendalakan karyawan itu. Meskipun seorang individu mungkin bersedia dan mampu, bisa saja ada rintangan yang menjadi penghambat.

Secara etimologi kata kinerja diartikan sebagai suatu yang dicapai, prestasi yang diperlihatkan, dan kemampuan kerja. Di dalam Contemporary English Indonesia Dictionary mengatakan bahwa istilah kinerja (performance) digunakan bila seseorang menjalankan tugas atau proses dengan terampil sesuai prosedur dan ketentuan yang ada.

Di lain pihak kinerja didefenisikan sebagai kualitas dan kuantitas dari pencapaian tugas-tugas yang dilakukan individu, kelompok, maupun organisasi. Kinerja selalu merupakan tanda keberhasilan suatu organisasi dan orang-orang yang ada dalam organisasi tersebut.

Selanjutnya definisi kinerja pegawai menurut Mangkunegara (2005:67) adalah "Kinerja pegawai (hasil kerja) adalah hasil kerja secara kualitas dan kuantitas yang dicapai oleh seorang pegawai dalam melaksanakan tugasnya sesuai dengan tanggung jawab yang diberikan kepadanya". Oleh karena itu disimpulkan bahwa kinerja sumber daya manusia adalah prestasi kinerja atau hasil kerja (output) baik kualitas maupun kuantitas yang dicapai sumber daya manusia persatuan periode waktu dalam melaksanakan tugas kerjanya sesuai dengan tanggung jawab yang diberikan kepadanya.

\section{Hasil Penelitian Terdahulu}

Penelitian terdahulu adalah acuan dan pembanding yang dijadikan sebagai standar terhadap penelitian yang diteliti. Ada beberapa peneliti terdahulu yang telah meneliti mengenai faktor-faktor yang mempengaruhi prestasi kerja pegawai pada obyek penelitian yang berbeda dari masing-masing peneliti, seperti penelitian terdahulu sebagai berikut:

Pertama, Sukriani (2002) dengan judul tesis: "Analisis Faktor-faktor yang Berpengaruh Terhadap Kinerja Pegawai Badan Perencanaan Daerah Kabupaten Maros" 
Volume. 13, Nomor 2, Desember 2017

Halaman. 90-108
Anatisis Faktor-Faktor Yang Berpengaruh

Terhadap Kinerja Pegawai Badan

Pengelolaan Keuangan Daerah Propinsi Sulawesi Selatan

menyimpulkan bahwa secara parsial faktor yang signifikan paling dominan berpengaruh terhadap kinerja pegawai adalah faktor insentif.

Kedua, penelitian Supardin (2003) dengan judul: "Analisis Fakt' ktor yang Berpengaruh terhadap kinerja penyuluh keluarga berencana (PKB) di kabupaten Takalar" menyimpulkan bahwa faktor yang paling diminan berpengaruh terhadap kinerja pegawai adalah faktor motivasi kerja.

Ketiga, Farah Tenriawaru (2005) dengan judul: Analisis Faktor-faktor yang Berpengaruh terhadap Kinerja Kerja Pegawai pada Kantor Sekretaris Daerah Kota Makassar. Hasil penelitian membuktikan bahwa motivasi kerja, pengalaman kerja dan lingkungan kerja merupakan faktor-faktor yang mempengaruhi kinerja kerja pegawai, faktor-faktor tersebut berpengaruh signifikan baik secara simultan maupun parsial. Sedangkan faktor yang berpengaruh dominan terhadap kinerja kerja pegawai adalah motivasi kerja.

\section{Metode Penelitian}

\section{Populasi dan Responden}

Populasi dalam penelitian ini adalah seluruh pegawai pada Biro Keuangan Provinsi Sulawesi Selatan yang berjumlah 90 orang. Oleh karena populasi penelitian sangat kecil maka semua populasi di jadikan responden dengan menggunakan metode sensus.

\section{Analisis Data}

Untuk menguji hipotesis yang telah diajukan dalam penelitian ini, maka digunakan metode analisis:

1. Analisis secara deskriptif mengenai faktor-faktor yang berpengaruh terhadap kinerja pegawai pada Badan Pengelolaan Keuangan Daerah Provinsi Sulawesi Selatan.

2. Metode analisis regresi linier berganda untuk menganalisis faktor-faktor yang berpengaruh terhadap kinerja pegawai pada Badan Pengelolaan Keuangan Daerah Provinsi Sulawesi Selatan dengan rumus: (Sugiono,2008:277)

$$
\mathbf{Y}=\mathbf{b}_{0}+\mathbf{b}_{1} \mathbf{X}_{1}+\mathbf{b}_{2} \mathbf{X}_{2}+\mathbf{b}_{3} \mathbf{X}_{3}+\mathbf{e}_{\mathbf{i}}
$$

Dimana:

$\mathrm{Y}=$ Kinerja Pegawai

$\mathrm{X}_{1}=$ Motivasi Kerja 
Volume. 13, Nomor 2, Desember 2017

Halaman. 90-108
Analisis Faktor-Faktor Yang Berpengaruh

Terhadap Kinerja Pegawai Badan

Pengelolaan Keuangan Daerah Propinsi Sulawesi Selatan

$\mathrm{X}_{2} \quad$ = Lingkungan Kerja

$\mathrm{X}_{3} \quad$ = Budaya Kerja

$\mathrm{B}_{1}-\mathrm{b}_{3}=$ Koefisien Regresi

$\mathrm{b}_{0} \quad=$ Konstanta

$\mathrm{e}_{\mathrm{i}} \quad=$ Faktor Kesalahan

Selanjutnya untuk menentukan pengaruh dan tingkat signifikan $\alpha=0.05$ atau 5\% diuji dengan menggunakan uji-F dan uji-t melalui program komputer SPSS 15.

\section{Definisi Operasional}

1. Kinerja adalah hasil kerja maksimal yang di capai oleh pegawai dalam melaksanakan tugas dan tanggung jawabnya. Adapun indikatornya adalah penguasaan penyelesaian pekerjaan, kecepatan dalam menyelesaikan tugas, kecermatan hasil kerja, volume kerja dan kesuaian dengan target

2. Motivasi kerja adalah daya pendorong baik dari luar maupun dari dalam diri seseorang pegawai dalam melaksanakan kegiatan atau aktivitasnya sesuai tupoksi masing-masing, indikatornya adalah bentuk pengarahan atasan, sikap terhadap pekerjaan dan pemahaman atas tugas pokok dan fungsinya.

3. Lingkungan kerja adalah kondisi kerja yang aman, dinamis dan harmonis bagi semua pegawai dalam menjalankan aktivitas untuk mencapai tujuan organisasi. Indikatornya adalah suasana lingkungan kerja yang aman dan nyaman, tersedianya peralatan kerja, serta keharmonisan antar pegawai.

4. Budaya kerja adalah sikap dan prilaku serta tindakan yang ditunjukkan oleh setiap pegawai dalam melaksanakan tugas pokok dan fungsinya. Indikatornya adalah persepsi pegawai terhadap norma-norma yang di dalam organisasi, pemahaman pegawai terhadap budaya kerja, dan kemampuan melaksanakan budaya kerja.

Semua variabel dalam penelitian ini diukur dengan menggunakan Skala Likert. Penggunaan Skala Likert tersebut dilakukan dengan angka pilihan yang diarahkan dengan nilai terendah minimal 1 dan nilai tertinggi maksimal 5, yang selanjutnya dilakukan rating skor. 
Volume. 13, Nomor 2, Desember 2017

Halaman. 90-108
Anatisis Faktor-Faktor Yang Berpengaruh

Terhadap Kinerja Pegawai Badan

Pengelolaan Keuangan Daerah Propinsi Sulawesi Selatan

\section{Hasil Penelitian Dan Pembahasan}

\section{Hasil Penelitian}

Penelitian ini dimaksudkan untuk mengetahui dan menganalisis seberapa besar hubungan dan pengaruh variabel motivasi kerja (X1), lingkungan kerja (X2), dan budaya kerja (X3) terhadap Kinerja pegawai Badan Pengelolaan Keuangan Daerah Provinsi Sulawesi Selatan (Y) baik secara simultan maupun parsial.

Dalam analisis ini digunakan metode regresi berganda dengan bantuan program SPSS (Statistical Package for Social Science). Adapun output dari hasil perhitungan diperoleh koefisien regresi berganda sebagai berikut :

\section{$Y=-1,566+0,444 X 1+0,584 X 2+0,260 X 3$}

Interprestasi dari persamaan regresi berganda di atas tersebut dapat diuraikan sebagai berikut :

1. Bo $=$ dari persamaan regresi tersebut terlihat bahwa nilai konstanta sebesar $-1,566$ yang menyatakan bahwa jika tidak ada variabel motivasi kerja (X1), lingkungan kerja (X2), dan budaya kerja (X3). maka kinerja pegawai Badan Pengelolaan Keuangan Daerah Provinsi Selawesi Selatan akan mengalami penurunan.

2. Koefisien regresi untuk variabel X1 (Motivasi Kerja) sebesar 0,444 menunjukkan bahwa motivasi kerja mempunyai pengaruh positif terhadap kinerja pegawai Badan Pengelolaan Keuangan Daerah Provinsi Sulawesi Selatan.

3. Pada koefisien regresi untuk variabel X2 (Lingkungan Kerja) sebesar 0,584 menunjukkan bahwa lingkungan kerja yang nyaman dan kondusif dapat meningkatkan kinerja pegawai Badan Pengelolaan Keuangan Daerah Provinsi Sulawesi Selatan.

4. Hasil yang di peroleh untuk variabel X3 (Budaya Kerja) adalah 0,260. Koefisien regresi untuk variabel ini menunjukkan bahwa budaya kerja mempunyai pengaruh positif terhadap kinerja pegawai Badan Pengelolaan Keuangan Daerah Provinsi Sulawesi Selatan.

Sesuai persamaan regresi linier berganda tersebut di atas, dapat diketahui bahwa ternyata ke tiga (3) variabel independen tersebut berpengaruh positif terhadap kinerja pegawai Badan Pengelolan Keuangan Daerah Provinsi Sulawesi Selatan.

\section{Uji Serempak (Uji F)}

Hipotesis pertama sebagaimana dikemukakan pada bagian sebelumnya, bahwa "diduga variabel motivasi kerja, lingkungan kerja, dan budaya kerja berpengaruh terhadap 
Volume. 13, Nomor 2, Desember 2017

Halaman. 90-108
Anatisis Faktor-Faktor Yang Berpengaruh Terhadap Kinerja Pegawai Badan Pengelolaan Keuangan Daerah Propinsi Sulawesi Selatan

kinerja pegawai Badan Pengelolaan Keuangan Daerah Provinsi Sulawesi Selatan. untuk pengujian hipotesis pertama dilakukan uji F (uji serempak).

Tabel. 1. Uji Anova

\begin{tabular}{l|c|l|l|l|l}
\hline Model & Sum of aquares & Df & Mean square & F ig & S \\
\hline Regression & 40,169 & 3 & 13,390 & 41,108 & $000^{\mathrm{a}}$ \\
Residual & 28,012 & 86 &, 326 & & \\
total & 68,181 & 89 & & & \\
\hline
\end{tabular}

$\mathrm{R}=0,768$

$R^{2}=0,589$

Sumber, hasil regresi dari program SPSS

Dari tabel 1 di atas tergambar bahwa nilai F-hitung 41,108 sedangkan F-tabel sebagai pembanding adalah 2,72 dengan demikian diketahui F-hitung > F-tabel atau 41,108 > 2,72 dan $\mathrm{P}=0,000$ atau lebih kecil dari 0,05. Dengan demikian berarti bahwa secara statistik variabel motivasi kerja, lingkungan kerja, dan budaya kerja secara bersama-sama memiliki pengaruh yang bermakna terhadap kinerja pegawai Badan Pengelolaan Keuangan Daerah Propinsi Sulawesi Selatan.

Besarnya pengaruh variabel-variabel independen (3 variabel) tersebut dapat diketahui dari besarnya nilai koefisien determinan $\left(\mathrm{R}^{2}\right)$. Nilai koefisien determinan sesuai hasil perhitungan regresi liner adalah $\mathrm{R}^{2}=0,589$ atau 58,9\%. Hal inimenujukkan bahwa variabelvariabel independen tersebut secara bersama-sama memengaruhi variabel dependen sebesar $58,9 \%$ sedangkan sisanya sebesar $41,1 \%(100 \%$ - 58,9\%) dipengaruhi oleh variabel lain yang tidak dapat dijelaskan. Dengan demikian dapat disimpulkan bahwa hipotesis pertama di terima.

\section{Uji Parsial (Uji t)}

\section{Tabel 2}

\section{Data Hasil Analisis untuk Uji Parsial}

\begin{tabular}{|c|c|c|c|c|c|c|}
\hline \multicolumn{7}{|c|}{ Coefficients $^{\mathrm{a}}$} \\
\hline \multirow[t]{2}{*}{ Mo } & & \multicolumn{2}{|c|}{$\begin{array}{l}\text { Unstandardized } \\
\text { Coefficients }\end{array}$} & Standardized Coefficients & \multirow{2}{*}{$\mathrm{t}$} & \multirow[t]{2}{*}{ Sig. } \\
\hline & & $\mathrm{B}$ & SE & Beta & & \\
\hline \multirow{4}{*}{1} & Cons & $-1,566$ & 0.606 & & $-2,583$ & 0.011 \\
\hline & $\times 1$ & 0,444 & 0.083 & 0.406 & 5,355 & 0.000 \\
\hline & $x 2$ & 0,584 & 0.102 & 0.443 & 5,741 & 0.002 \\
\hline & $x 3$ & 0,260 & 0.119 & 0.157 & 2,179 & 0.032 \\
\hline
\end{tabular}

\section{Sumber: hasil spss}


Volume. 13, Nomor 2, Desember 2017

Halaman. 90-108
Analisis Faktor-Faktor Yang Berpengaruh

Terhadap Kinerja Pegawai Badan

Pengelolaan Keuangan Daerah Propinsi Sulawesi Selatan

Sebagaimana telah dikemukakan dalam teknik analisis bahwa uji ini bertujuan untuk mengetahui pengaruh masing-masing variabel independen terhadap variabel dependen, signifikan atau tidak. Dalam pembuktian hipotesis kedua tersebut, pengujian ini dilakukan dengan membandingkan antara nilai t-hitung masing-masing variabel independen dengan nilai $\mathrm{t}$-tabel $=1,99$ yang menggunakan derajat kesalahan $5 \%$.

Ada pun pengujian variabel-variabel independen terhadap kinerja pegawai Badan Pengelolaan Keuangan Daerah Provinsi Sulawesi Selatan, adalah sebagai berikut :

a. Variabel motivasi kerja $\left(\mathrm{X}_{1}\right)$, nilai t-hitung $=5,355$ dan $\mathrm{t}$-tabel $=1,99$, maka $\mathrm{t}$-hitung $>\mathrm{t}$ tabel, yang berarti memiliki pengaruh yang signifikan.

b. Variabel lingkungan kerja (X2) nilai t-hitung $=5,742$ dan t-tabel $=1,99$, maka t-hitung > t-tabel, yang berarti memiliki pengaruh yang signifikan.

c. Variabel budaya kerja nilai t-hitung $=2,179$ dan $\mathrm{t}$-tabel $=1,99$ maka t-hitung $>\mathrm{t}$-tabel, yang berarti memilki pengaruh yang signifikan

Berdasarkan hasil penelitian tersebut maka dapat disimpulkan bahwa variabel independen yang memiliki pengaruh paling signifikan terhadap kinerja pegawai Badan Pengelolaan Keuangan Daerah Propinsi Sulawesi Selatan adalah variabel lingkungan kerja $\left(\mathrm{X}_{2}\right)$ dengan nilai $\beta=$ paling besar yaitu 0,443 dengan demikian hipotesis kedua diterima.

\section{Pembahasan}

Pentingnya faktor-faktor yang meningkatkan kinerja pegawai merupakan upaya yang harus dilakukan secara berkelanjutan dan berkesinam bungan. Ketiga faktor-faktor tersebut di atas, masing-masing dapat dijelaskan dan terurai, bagaimana pengaruhnya terhadap kinerja pegawai sebagai berikut :

\section{Variabel Motivasi Kerja}

Berdasarkan hasil analisis penelitian ini telah membuktikan bahwa motivasi kerja pegawai Badan Pengelolaan Keuangan Daerah Provinsi Sulawesi Selatan cukup tinggi dan hal ini dapat diperkuat oleh hasil penelitian melalui hasil analisis deskripsi tanggapan dari masing-masing pegawai yang menunjukkan sebanyak 55 orang atau $61 \%$ pegawai mengatakan bahwa dalam melakukan tugas selalu optimis dan berusaha keras untuk mencapai target pekerjaan sedangkan sisanya 35 orang atau $49 \%$ pegawai kurang termotivasi dalam mengerjakan tugasnya. Meskipun demikian motivasi kerja menunjukkan adanya hubungan yang kuat dengan kinerja pegawai, namun demikian motivasi kerja perlu ditingkatkan supaya 
Volume. 13, Nomor 2, Desember 2017

Halaman. 90-108
Analisis Faktor-Faktor Yang Berpengaruh

Terhadap Kinerja Pegawai Badan

Pengelolaan Keuangan Daerah Propinsi Sulawesi Selatan

peningkatan kinerja pegawai Badan Pengelolaan Keuangan juga dapat terpelihara dengan baik dan terutama dalaam meningkatkan kinerja lembaga.

Sedangkan secara inferensial statistic melalui regresi berganda juga menunjukkan bahwa motivasi kerja berpengaruh positif dan signifikan terhadap kinerja pegawai Badan Pengelolaan Keuangan Daerah Provinsi Sulawesi Selatan dengan nilai thitung $=5,355$ dan signifikansi (probabilitas) $=0.000<0.005$ dan sumbangan penelitian ini di gambarkan dalam koefisien regresinya yang mencapai 44,4\%. Dengan demikian, maka motivasi kerja pegawai Badan Pengelolaan Keuangan Daerah Provinsi Sulawesi Selatan dapat dipertahankan dan kalau bisa dapat ditingkatkan.

Berdasarkan hasil penelitian yang telah dikemukakan di atas baik melalui analisis deskriptif maupun inferensial statistic regresi berganda, maka penelitian ini sependapat dengan Robinson, (1999:50) mengatakan bahwa motivasi adalah kesediaan untuk melaksanakan upaya tinggi untuk mencapai tujuan-tujuan keorganisasian, yang dikondisikan oleh kemampuan upaya untuk memenuhi kebutuhan individual tertentu sesuai dengan hasil kerja.

\section{Variabel Lingkungan Kerja}

Lingkungan kerja yang kondusif dapat memotivasi kerja setiap pegawai dalam melaksanakan tugasnya dengan baik, oleh karena itu maka perlu adanya upaya untuk memperbaiki lingkungan dan sarana kerja yang lebih baik sesuai dengan kebutuhan kerja pegwai. Lingkungan dan sarana kerja yang kondusif dapat memberi dukungan kerja sehingga dapat mendorong pegawai untuk bersemangat meningkatkn pekerjaannya baik secara kuantitas maupun kualitasnya. Untuk menggambarkan lingkungan kerja yang kondusif, maka diperlukan adanya penataan lingkungan kerja yang dapat memberikan nuansa kerja yang memiliki suasana yang menyenangkan bagi setiap pegawai.

Berdasarkan analisis hasil penelitian ini menunjukkan bahwa terdapat pengaruh posistif dan paling signifikan antara lingkungan kerja dengan kinerja pegawai Badan Pengelolaan Keuangan Daerah Provinsi Sulawesi Selatan. Lingkungan kerja ini dapat memenuhi sebagian dari kebutuhan dan keinginan pegawai terutama dalam akativitas kerja sehari-hari. Meskipun secara keseluruhan telah di sadari juga bahwa masih banyak kondisi lingkungan kerja yang belum dapat memenuhi semua kebutuhan kerja pegawai. Pada umumnya situasi lingkungan kerja di rasakan oleh para pegawai yang berkenan dengan 
Volume. 13, Nomor 2, Desember 2017

Halaman. 90-108
Analisis Faktor-Faktor Yang Berpengaruh

Terhadap Kinerja Pegawai Badan

Pengelolaan Keuangan Daerah Propinsi Sulawesi Selatan

aktivitas kerja yang di lakukan dapat di tunjukkan dalam bentuk suasana ruangan kerja yang cukup menyenangkan, ruangan istirahat dan tempat untuk ibada dan lingkungan sekitar kantor juga dapat mendukung semangat kerja pegawai.

Hasil analisis penelitian ini juga membuktikan bahwa lingkungan kerja yang ada pada Badan Pengelolaan Keuangan Daerah Provinsi Sulawesi Selatan dan hal ini dapat di perkuat oleh hasil penelitian melalui deskripsi tanggapan dari responden dari masing-masing pegawai yaitu mencapai 51 orang atau $65 \%$ pegawai yang mengatakan bahwa lingkungan kerja kondusif dan sangat kondusif untuk bekerja. Oleh karena itu, situasi dan kondisi lingkungan kerja sangat perlu untuk di kelolah dengan baik melalui upaya penataan ruangankerja, istirahat, ibadah dan lain-lain sehingga dapat menciptakan semangat kerja yang tinggi.

Sedang secara infererensial statistik melalui regresi berganda juga menunjukkan bahwa lingkungan kerja berpengaruh positif dan signifikan terhadap kinerja pegawai Badan Pengelolaan Keuangan Daerah Provinsi Sulawesi Selatan dengan nilai thitung $=5,741$ dan signifikansi (probabilitas) $=0,002<0,005$ dan sumbangan penelitian ini digambarkan dalam koefisien regresi yang mencapai 58,4\%. Dengan demikian, maka lingkungan kerja yang kondusif dapat dipertahankan dan kalau bisa ditingkatkan penataannya yang dapat disesuaikan dengan perubahan lingkungan kerja pegawai.

Sejalan dengan hasil penelitian baik secara deskriptif maupun inferensial statistic regresi berganda yang telah di kemukakan maka penelitian ini dapat mendukung hasil penelitian Burhanuddin (2004), bahwa lingkungan kerja berpengaruh terhadap kinerja pegawai Dinas Pendapatan Daerah Kabupaten Maros, juga memperkuat hasil penelitian Abdi Majid Dollah (2005), bahwa lingkungan kerja berpengaruh positif dan signifikan terhadap kepuasan kerja pegawai negeri sipil pada Dinas Kehutanan Kabupaten Kolaka.

\section{a. Variabel Budaya Kerja}

Budaya kerja yang terpleihara dengan kuat dan positif dalam organisasi dapat mendorong perilaku pegawai yang baik untuk meningkatkan kinerjanya. Budaya kerja dapat menciptakan iklim kerja yang dapat menjamin terciptanya suasana hubungan kerja yang baik terhadap atasan sesame pegawai dan bahkan tercipta hubungan kekeluargan dalam organisasi. Budaya organisasi berfungsi sebagai pedoman bersikap, berprilaku dan bertindak sehingga setiap pegawai dapat bekerja dengan penuh rasa tangung jawab terhadap tugas-tugas yang diberikan oleh manajemen. 
Volume. 13, Nomor 2, Desember 2017

Halaman. 90-108
Anatisis Faktor-Faktor Yang Berpengaruh

Terhadap Kinerja Pegawai Badan

Pengelolaan Keuangan Daerah Propinsi Sulawesi Selatan

Hasil analisis penelitian membuktikan bahwa budaya kerja berpengaruh positif terhadap kinerja pegawai Badan Pengelolaan Keuangan Daerah Provinsi Sulawesi Selatan dan hal ini diperkuat oleh hasil penelitian melalui deskripsi tanggapan dari responden yang mencapai 61 orang atau $71 \%$ pegawai yang mengatakan setuju dan sangat setuju. Oleh karena itu, budaya kerja sangat perlu untuk direspon dengan baik melalui upaya sosialisasi baik manfaatnya kepada pegawai maupun kepada lembaga sehingga dapat menciptakan semangat kerja yang memiliki nilai kebersamaan untuk meningkatkan kinerja pegawai dalam lingkungan Badan Pengelolaan Keunagan Daerah Provinsi Sulawesi Selatan.

Sedangkan secara inferensial statistic regresi berganda juga menunjukkan bahwa budaya kerja berpengaruh positif dan signifikan terhadap kinerja pegawai dengan nilai thitung $=$ 2,179 dan tingkat signifikansi (probabilitas) $=0,0<0,05$ dan sumbangan penelitian ini di gambarkan dalam koefisien regresinya yang mencapai $26 \%$. Dengan demikian, maka budaya kerja yang kuat dan memiliki nilai positif dapat dipertahankan.

Hasil penelitian ini menunjukkan bahwa peningkatan kinerja pegawai sangat ditentukan oleh budaya kerja yang terpelihara kuat dalam organisasi dengan dukungan perlemgkapan organisasi. Hasil penelitian ini mendukung dan memperkuat konsep yang telah dikemukakan oleh Kreitner dan Kinicki (200), bahwa prngelolaan organisasi berpusat pada budaya kerja dalam pemberdayaan sumber daya manusia, produk (kualitas layanan), proses manajemen (pembelajaran, teknologi, dan pengembangan) dan produktivitas kerja (kinerja) organisasi.

\section{SIMPULAN DAN SARAN}

\section{Simpulan}

Berdasarkan hasil penelitian di atas, maka ditarik simpulan sebagai berikut:

1. Secara simultan motivasi kerja, lingkungan kerja, dan lingkungan kerja berpengaruh positif dan signifikan terhadap kinerja pegawai Badan Pengelolaan Keuangan Daerah Provinsi Sulawesi Selatan.

2. Secara parsial motivasi kerja berpengaruh secara signifikan terhadap kinerja Badan Pengelolaan Keuangan Daerah Provinsi Sulawesi Selatan.

3. Secara parsial Lingkungan kerja berpengaruh dominan dan signifikan terhadap kinerja pegawai Badan Pengelolaan Keuangan Daerah Provinsi Sulawesi Selatan 
Volume. 13, Nomor 2, Desember 2017

Halaman. 90-108
Anatisis Faktor-Faktor Yang Berpengaruh

Terhadap Kinerja Pegawai Badan

Pengelolaan Keuangan Daerah Propinsi Sulawesi Selatan

4. Secara parsial Budaya kerja berpengaruh positif dan signifikan terhadap kinerja pegawai Badan Pengelolaan Keuangan Daerah Provinsi Sulawesi Selatan

\section{Saran}

Berdasarkan kesimpulan yang dikemukakan di atas, maka perlu diberikan suatu saran yang menjadi rekomendasi bagi Badan Pengelolaan Keuangan Daerah Provinsi Sulawesi Selatan. dalam rangka meningkatkan kinerja pegawai, sebagai berikut:

1. Untuk meningkatkan kinerja pegawai Badan Pengelolaan Keuangan Daerah Provinsi Sulawesi Selatan maka diperlukan adanya motivasi kerja, berupa selalu optimis dalam menyelesaikan tugas, lingkungan kerja yang kondusif dan budaya kerja.

2. Lingkungan kerja yang sangat di butuhkan oleh Badan Pengelolaan Keuangan Daerah Provinsi Sulawesi Selatan karena faktor ini yang berpengaruh paling dominan

3. Untuk peneliti selanjutnya di Badan Pengelolaan Keuangan Daerah Provinsi Sulawesi Selatan disarankan untuk meneliti dengan judul yang sama dengan variab ; berbeda mengingat masih ada sekitar 41,10\% varibel lain yang belum diteliı yang dapat mempengaruhi kinerja pegawai.

\section{DAFTAR PUSTAKA}

Davis, Keith. (1989), Human Behavior At Work: Organization Behavior. New York.McGraw Hill International.

Donald McEachern, Thomas, 2004. Motivation of Personal Satisfied In Prospective Theories. http://www.journalmotivation.com.id.

Gibson, James L., John M. Ivancevic dan James H. Donnely, 2004. Organisasi dan Manajemen. Terjemahan: Djarkasih, Edisi Keempat, Erlangga, Jakarta.

Gomes, Faustimo Cardoso, 1999, Manajemen Sumber Daya Manusia, Cetakan Ketiga, Andi Offset, Jakarta

Gybertz, Santaz, 2003. Basic Motivation amd The Role It. http://www.journalmotivation.com.id.

Handoko, T. Hani. (1998), Manajemen Personalia dan Sumber Daya Manusia, Jakarta, Badan Penerbitan Fakultas Ekonomi UI.

Hasibuan, SP. Melayu, (1999). Organisasi dan Motivasi. Jakarta. Cet. kedua. Jakarta. Bumi Aksara.

(2005). Organisasi dan Motivasi. Jakarta. cet. kelima, Bumi Aksara. 
Volume. 13, Nomor 2, Desember 2017

Halaman. 90-108
Analisis Faktor-Faktor Yang Berpengaruh Terhadap Kinerja Pegawai Badan Pengelolaan Keuangan, naerah Propinsi Sulawesi Selatan

Jack, Frederick, 2003. Safety and Saving by Employee in Job Activity. http://www.sociallabor.com.id.

Jackson, Korten, 2004. Post of Motivation on Corporation World. Penerbit Obor Indonesia, Jakarta.

Mangkunegara, A.A. Anwar Prabu. 2005. Perilaku dan Kinerja Organisasi. PT. Refika Aditama - Bandung

Martoyo, 1992. Motivasi dan Jenis-jenis Motivasi. Penerbit Liberty, Yogyakarta.

Martuli, Kuncoro, 2001. KualitasSumber Daya Manusia, Erlangga, Jakarta.

Moekijat, (1995), Manajemen Personalia dan Sumberdaya Manusia, Bandung, Mandar Maju.

Nitisemito A.S, 1986, Manajemen Personalia, PT. Ghalia Indonesia, Jakarta

Nawawi, Handari, 2004, Manajemen Sumber Daya Manusia, Gajah Mada Universitas Press, Yogyakarta

Siagian P, Sondang. (2004), Teori Motivasi dan Aflikasinya, Jakarta.,Renika Cipta.

Simamora, Henry, 1997. Manajemen Sumber Daya Manusia, STIE, YKPN, Yogyakarta.

Subarka,Fuad, 2000. Manajemen Sumber Daya Manusia-Kualitas SDM, Prehalindo,Jakarta

Thalib, Ramadhan, 1995. Kualitas Sumber Daya Manusia, Rajawali Press, Jakarta.

Thoha Miftah, 1996, Perilaku Orgaanisasi Konsp Dasar dan Aplikasi, Grafisno Persada, Jakarta

Tunggal, Amid Widjaja, 2005. Tanya Jawab: Motivasi, Kepuasan, Perilaku Konsumen dan Pemasaran Strategi. Penerbit Harvarindo, Jakarta.

Umar, Husain. 2000. Pengembangan Sumber Daya Manusia. Pustakajaya, Jakarta.

2004, Pembinaan Organisasi, Proses Diagnosa dan Intervensi, PT. Raja Grafindo Persada, Jakarta.

Tunggal, Amid Widjaja, 2005. Tanya Jawab: Motivasi, Kepuasan, Perilaku Konsumen dan Pemasaran Strategi. Penerbit Harvarindo, Jakarta.

Terry, GR. (1988). Asas-asas Manajemen, cetakan keenam, Bandung, Alumni Bandung

Tribawono, Ginanjar, 1999. Defenisi Kualitas SDM dalam Kinerja, Rineka Cipta, Jakarta.

Winardi, (2003). Teori Organisasi dan Pengorganisasian, Jakarta, PT. RajaGrafindo Persada

Zainun, Buchari. (1989). Manajemen dan Motivasi, Jakarta, Balai Aksara. 